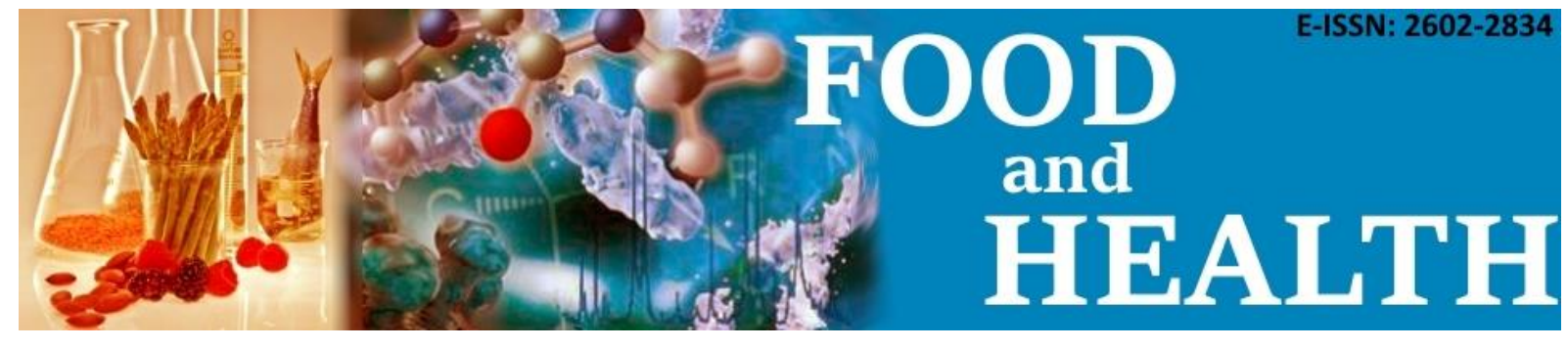

\title{
ANTIMICROBIALS USED IN ACTIVE PACKAGING FILMS
}

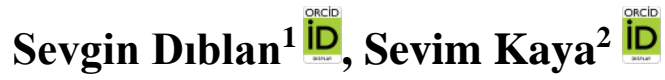 \\ ${ }^{1}$ Department of Food Engineering, Faculty of Engineering, Adana Science and Technology University, Adana, Turkey \\ 2 Department of Food Engineering, Faculty of Engineering, Gaziantep University, Gaziantep, Turkey
}

Received: 14.07 .2017

Accepted: 17.10.2017

Published online: 22.11.2017
Corresponding author:

Sevgin Diblan, Department of Food Engineering, Faculty of Engineering, Adana Science and Technology University, Adana, Turkey

E-mail: sdiblan@adanabtu.edu.tr

\begin{abstract}
:
Active packaging technology is one of the innovative methods for preserving of food products, and antimicrobial packaging films is a major branch and promising application of this technology. In order to control microbial spoilage and also contamination of pathogen onto processed or fresh food, antimicrobial agent(s) is/are incorporated into food packaging structure. Polymer type as a carrier of antimicrobial can be petroleumbased plastic or biopolymer: because of environmental concerns researchers have lean to development of biodegradable antimicrobial films. Antimicrobial substances can be organic acids, parabens, sulfites, nitrites, phosphates, alcohols, antibiotics and bacteriocins. Succeed of antimicrobial film mainly depends on antimicrobial agent selection that antimicrobial should be chosen according to the food type packed, and deteriorative microbial flora of it. This review discussed the recent application of antimicrobial-active films for food protection. Also, their activity mechanisms against microorganisms, the effects of antimicrobials on food quality and of the film properties were presented.
\end{abstract}

Keywords: Active packaging, Antimicrobial, Food quality, Film properties 


\title{
Food and Health, 4(1): 63-79 (2018)
}

\author{
Journal abbreviation: Food Health
}

\section{Introduction}

Food products have different deterioration mechanisms; microbial, biochemical, physical, textural and chemical based on their ingredients, production techniques used, packaging type applied, etc. However, microbial deterioration mechanism is accepted that is dominant over the others. There are various food process technologies to prolong the shelf life of the products such as heat treatment, canning, and dehydration. However, there are certain needs for packaging to protect foods during handling, distribution or storage whatever processes applied since the main focus of food packaging is to protect the product from environmental hazards (for examples, moisture lost or gain, possible dust and insect contact) which may adversely affect its quality.

In recent years, the tendency is to decrease as much as possible amount of chemical used in food products whether they are harmful or not to human body. The consumers demand fresh-like (minimally processed), rich in nutritional value, wholesome and also shelf-stable, and easily prepared foods. According to European Food Safety Authority (EFSA) reports (2011), during 2009, 5550 foodborne outbreaks were reported resulting 46 deaths (Sohaib, Anjum, Arshad, \& Rahman, 2016). Additionally, the world population is increasing faster than food supply sources. Yet, it was reported that, in Turkey, the edible food wastes in a single household were $298 \mathrm{~kg} / \mathrm{year}$ (Pekcan, Köksal, Küçükerdönmez, \& Ozel, 2006). Wasting food products (post or pre-harvest), and new marketing trend have led to emerge new technologies in packaging such as modified atmosphere packaging, intelligent and/or active packaging. Active packaging technology containing suitable additives is capable of adsorbing moisture and carbon dioxide or releasing of preservative substances such as antimicrobials or antioxidants (Brennan \& Grandison, 2012).

Since the microbial deterioration is mainly responsible for spoiling the foods, packaging films incorporated with antimicrobial agent is one of the promising application areas of active packaging technologies. Antimicrobial agents (such as imazalil, silver or potassium sorbate) can be diffused in small amount from films into the food surface where the most microbial contamination occurs. In this way, the microbial safety and shelf life of food product is significantly improved without using any additives directly by means of dipping, spraying etc. The direct usage of antimicrobial agents in food system is restricted due to the possible diffusion of agents into food bulks, and concentration of antimicrobials at food surface reduces and eventually, resulting in microbial growth and spoilage at surface. The antimicrobial effectiveness of these agents depends on diffusion of agents into the food surface from packaging material. Antimicrobial effect or microbial inhibition can be achieved by slow diffusion into food surface by a carrier which is a package material. By this way, the diffusion of antimicrobial agent into food core is prevented and the agents diffuse into food surface where the main place for microbial growth is (Teerakarn, Hirt, Acton, Rieck, \& Dawson, 2002).

The active packaging researches have deal with antimicrobial effects of antimicrobial agent and diffusion of antimicrobial agent into model system mostly. This review mainly focused on types and activity mechanisms of antimicrobial-active films suggested for food protection and the effects of them on food quality parameters and film properties.

\section{Active Packaging}

Active packaging technology can be defined as a packaging technique adds antimicrobial, antioxidants or other quality enhancer agents via coating packaging materials and let the active packaging agent released into the packed food in small amount to ensure the safety of foods. Among various types of active packaging application, the attention in active packaging with antimicrobial substances has been increased considerably (Imran, Klouj, Revol-Junelles, \& Desobry, 2014; Mauriello, De Luca, La Storia, Villani, \& Ercolini, 2005). Table 1 summarizes the recent active chemicals used in active packaging with the aim of their applications, and lists the possible carrier medium of the agents and applied food products.

The factors that should be considered while choosing antimicrobial agent are antimicrobial spectrum and mode of action of the agent, chemical composition of food and the agent, diffusion kinetics of agents from polymers, the concentration of antimicrobial agents in polymer, polymer type selected and agent, polymer and food interactions. For example nutrient rich media of foods can reduce the activity of silver zeolite, also emulsifier 


\section{Food and Health, 4(1): 63-79 (2018)}

\section{Journal abbreviation: Food Health}

or fatty acids can affect nisin activity (Appendini \& Hotchkiss, 2002).

Types of antimicrobial packaging can be divided into five basic applications (Appendini \& Hotchkiss, 2002):

- Volatile antimicrobial agent addition into sachet and pads: Chlorine dioxide, ethanol and sulfur dioxide or volatile essential oils are the volatile antimicrobial agents which are often enclosed separately in sachets/pads attached to the internal part of the package. These agents will be vaporizing to the headspace of packaging and vapor-gas form of antimicrobial agent can contact with food products (Sung et al. 2013). Also, because of the ability of oxygen reduction, oxygen absorbers may be in this class. Oxygen absorbers (e.g. iron powder) are able to inhibit the growth of aerobic microorganisms and mold. Moisture absorbers (e.g. silica gels) can also affect the microbial growth due to reduction in water activity.

- Antimicrobial agents incorporated into polymer: Antimicrobial agents can be incorporated into polymers such as edible films, LDPE and various polyolefin. Especially in Japan, silver substituted zeolites are widely used with polymers (1-3\%) (Appendini \& Hotchkiss, 2002). There is another method known as solution-casting method. It includes preparation of a film blend containing antimicrobial agent, then, film can be casted above a suitable and smooth ground. Especially this casting method is used with production of active edible or biodegradable films. Film forming can be done using an extruder also.

- Coating polymer surfaces with antimicrobials: If the antimicrobial is heat sensitive, forming methods of active packaging film destructs its activity, the antimicrobial agents can be coated right onto the film material before applying to foods. In this technique, after blending of film solution, casting is done without antimicrobial agent. Then, another solution including antimicrobial is prepared and film will be covered by this solution and dried.

- Antimicrobials immobilized by ionic or covalent linkages to polymers: For this type of application there are a lot of required criteria: Polymer should be good properties of elasticity, stretch and conductivity; immobilization technique, non-covalent or covalent, should be selected according to the purpose of antimicrobial packaging system. For instance, if slow antimicrobial release is desired, covalent linkages should be preferred. This is why covalent linkages are mostly applied in antimicrobial packaging (Goddard \& Hotchkiss, 2007). Surface should be modified using a suitable technique in order to attach antimicrobial agent. After this process steps, the releasing rate of the antimicrobials to protect its activity over a time period which is an important parameter, can be controlled.

- Use of polymers which are inherently antimicrobial: Polymers that have antimicrobial effects are used such as chitosan or poly-L-lysine. Also, UVtreated nylon films show bactericidal effects.

\section{Properties and Activity Mechanism of Antimicrobials}

Antimicrobial agents used in films can be organic acids, metals, antibiotics, bacteriocins, enzymes, chelating agents, spices etc. (Ozdemir \& Floros, 2004). Table 1 represents brief information about studies focused on antimicrobial food packaging applications. Since the antimicrobial agent used in active films can be migrated into the food bulks, they should be considered as food additives and must meet the food additives standards (Appendini \& Hotchkiss, 2002).

\section{Organic acids}

Organic acids are used in food industry as acidulates and antimicrobials widely because of their solubility, flavor, and low toxicity. Organic acids such as sorbic acid, acetic acid, lactic acid and benzoic acids have long usage history in food industry and they are recognized as safe (GRAS) (Cruz-Romero, Murphy, Morris, Cummins, \& Kerry, 2013; Sohaib et al., 2016).

Sorbic acid that is an organic acid has been used as antimicrobial agent in food technology in recent years. The direct usage methods of sorbates in foods are varied that are dipping, spraying or dusting. Sorbic acid and its potassium, calcium or sodium salts are called as sorbates. Sorbic acid (pKa $=4.75$ ) is a trans-trans, unsaturated monocarboxylic acid $\left(\mathrm{CH}_{3}-\mathrm{CH}=\mathrm{CH}-\mathrm{CH}=\mathrm{CH}-\mathrm{COOH}\right)$. This acid has low solubility in water $(15 \mathrm{~g} / 100 \mathrm{~mL})$ while salt forms are highly soluble in water (58.2 $\mathrm{g} / 100 \mathrm{~mL}$ at $20^{\circ} \mathrm{C}$ ) (Branen, Davidson, Salminen, \& Thorngate, 2001), therefore in food industry sorbates are widely preferred as preservatives.

Some yeast such as Brettanomyces, Candida, Debaryomyces, Hansenula, Torulopsis and the molds such as Alternaria, Aspergillus, Botrytis, 


\section{Food and Health, 4(1): 63-79 (2018)}

\section{Journal abbreviation: Food Health}

Fusarium, Mucor, and Penicillium can be inhibited by sorbates. Also, in literature, antimicrobial activity of sorbic acid has been evaluated against yeast and mold generally (Table 1). However, antibacterial activity has also been observed against some bacteria such as Staphylococcus, Escherichia coli and Listeria monocytogenes.

The mechanism of sorbic acids against microbial growth lethally is partly due to the effects on enzymes such as dehydrogenases. Sorbate can turn the enzymes into the more stable forms such as thiohexenoic acid derivate and inhibit the enzyme activity in microorganism cell (Branen et al., 2001). The efficiency of sorbic acid is dependent on $\mathrm{pH}$ of the environment, with increasing $\mathrm{pH}$ the efficiency is decreased and after $\mathrm{pH} 6.5$, sorbic acid loses its antimicrobial properties, that is why the $\mathrm{pH}$ level is very important for such kind of the films (Perez, Soazo, Balague, Rubiolo, \& Verdini, 2014; Rodriguez-Martinez et al., 2016).

It had been reported that sorbic acid is one of least harmful antimicrobial agent used in food product: $\mathrm{LD}_{50}: 7.4-10.5 \mathrm{~g} / \mathrm{kg}$ body weight. Sorbic acid is used as preservatives with different concentrations into various food types such as drinks, dough, cakes, cake mixes, sausages casing.

Sorbic acid and its derivatives can be incorporated into any type of packaging materials (biodegradable or petroleum polymer) by mixing in solution and casting mostly. There are some articles showing application of sorbate containing active packaging films for food protection instead of adding sorbates into food itself: Hauser and Wunderlich (2011) proposed using sorbic acid incorporated packaging films (PVA) to inhibit the growth of contaminated microorganism that are Escherichia coli, Listeria monocytogenes, Saccharomyces cerevisiae on the surfaces of Gouda cheese and pork loin (Hauser \& Wunderlich, 2011) and they had suggested that antimicrobial film containing sorbic acid is able to prevent and reduce the growing of pathogens on food surfaces. Silveira, Soares, Geraldine, Andrade, and Goncalves (2007) had studied antimicrobial efficiency of potassium sorbate and its migration from active film into pastry dough. They found that there was not any statistical difference between films containing 3 or $7 \%$ potassium sorbate with respect to diffusion rate. It had been stated that Stapylococcus spp. could not be inhibited while there was $2 \log$ reduction in aerobic mesophilic count in dough wrapped with $7 \%$ film.
Benzoic acid and its derivate was the first antimicrobial agent approved and permitted by Food and Drug Administration (FDA). This organic acid can be found in many fruit and vegetables naturally. The maximum usage concentration of benzoic acids is between $0.15-0.25 \%$ in many countries (Dobias, Chudackova, Voldrich, \& Marek, 2000). Benzoic acid is used for its antimycotic activity. Same as sorbic acid, the salts form of benzoic acid such as sodium benzoate is more soluble in water than benzoic acid itself. Most yeast and molds can be inhibited by benzoic acid (20-2000 $\mu \mathrm{g} / \mathrm{mL}$ ) (Branen et al., 2001). The inhibition mechanism of microorganisms by benzoic acid has not been clear.

The addition of benzoic acids and its derivate into a polymer matrix such as LDPE can lead to significant changes into polymer film properties such as oxygen, water vapor or carbon dioxide permeability, tensile or sealing strength. On the other hand it was reported that the shelf life of bread and cheese wrapped with LDPE films containing benzoic acid had been improved due to the antifungustic efficiency of benzoic acids (Dobias et al., 2000). Benzoic acids are also effective against bacteria such as Bacillus cereus, Staphylococcus aureus, Pseudomonas fluorescens, and Escherichia coli (Cruz-Romero et al., 2013).

Lactic, tartaric, malic, and acetic acids are other organic acids used in food industry. Acetic acids can be lethal for Salmonella and its strains, especially with another antimicrobial i.e. combining with carvacrol, acetic acid can inhibit S. typhimurium growth on the poultry meat without affecting the flavor (Zhou et al., 2007). Tartaric and malic acids are found in fruits mostly and their antimicrobial capacities are not strong as other organic acids mentioned above. However, some researchers had reported they can suppress the growth of Salmonella if just together with under vacuum condition (Sohaib et al., 2016).

\section{Natural Microbial Metabolic Compounds}

Food consumer preference tendency has been changing to natural and additive-free food product; therefore scientists have been looking for some natural additives such as essential oil from plants or nisin from bacteria for providing wholesomeness and safety of foods. Bacteriocins are antimicrobial peptides that are metabolic products of different bacterial strains (Sohaib et al., 2016). Among bacteriocins, nisin is one of the most pre- 


\section{Food and Health, 4(1): 63-79 (2018)}

\section{Journal abbreviation: Food Health}

ferred bacteriocin as an antimicrobial agent. Lactic acid bacteria (LAB) bacteriocins such as nisin are heat-stable small peptides and can be divided basically into two classes: Class I and II. Class I bacteriocins is also called as lantibiotics that contain amino acids such as lanthionine in their structure (Zendo, Nakayama, Fujita, \& Sonomoto, 2008). Nisin is a 34 polypeptide bacteriocin, contains dehydroalanine and dehydrobutyrine residues and it is produced by Lactococcus lactis subsp. lactis (Liu \& Hansen, 1990).

Nisin has been approved as non-toxic and recognized as E234 by FDA and widely used in food industry. In France, the use of nisin in preservation of cheese was allowed without any limitation (Ripoche, Chollet, Peyrol, \& Sebti, 2006). The activity of nisin is against of Listeria monocytogenes and Staphylococcus aureus that are gram positive bacteria (Imran et al., 2014; Sebti, Carnet, Blanc, Saurel, \& Coma, 2003) and also it can combine with a chelator agent resulting activated against gram negative bacteria (Teerakarn et al., 2002). The cytoplasmic membrane of gram positive bacteria is the target of nisin; this antimicrobial agent causes the pores onto the membrane of microorganism's cell wall resulting in degradation of proton motive force and loss cellular ions, amino acids and ATP. Because of the outer membrane of gram negative bacteria which perform as barrier against hydrophobic solutes and macromolecules, gram negative bacteria is resistant to antimicrobial effects of nisin (Olasupo, Fitzgerald, Gasson, \& Narbad, 2003). As mentioned above, nisin has known antibacterial activity against gram positive bacteria and with a chelating agent also against gram negatives. This has been shown by Bhatia and Bharti (2015); they have reported that antibactericidal attacks against gram negative bacteria increased with increasing EDTA concentration into film blend (Table 1).

Nisin solubility is affected with $\mathrm{pH}$ changes resulting in antimicrobial activity loss (Liu \& Hansen, 1990). It was reported that the solubility is higher at low $\mathrm{pH}(57 \mathrm{mg} / \mathrm{mL}$ at $\mathrm{pH} 2)$ and is significantly lower at high $\mathrm{pH}(0.25 \mathrm{mg} / \mathrm{mL}$ at $\mathrm{pH} 8$ to 12$)$. In a study, it was reported that the effectiveness onto the Micrococcus luteus and release mechanism of nisin was $\mathrm{pH}$ and temperature dependent (Mauriello et al., 2005). Nisin efficiency in food product is related with the diffusion rate of nisin from films into food surface. However, in order to enhance antimicrobial efficiency, some researches have preferred coating techniques considering nature of nisin. The diffusion of nisin can be affected with possible factors such as nisin concentration, storage conditions, and film types used (edible or biopolymer etc.) (Ripoche et al., 2006).

Natamycin, also known as primaricin or pimaricin, is another metabolic product used as preservative in foods and produced by Streptomyces natalensis. Natamycin was approved by FDA as GRAS and by European Union as natural preservative as E235 (Bierhalz, da Silva, \& Kieckbusch, 2012; Fucinos et al., 2015). Natamycin can inhibit fungal growth and causes cell lyses of binding to cell membrane sterols (Duran et al., 2016). The most popular usage of natamycin is as spray, applied directly over cheese and sausages up to level of $1 \mathrm{mg} / \mathrm{dm}^{2}$ (Lantano et al., 2014). In a study, fresh strawberry had been coated using chitosan edible films with natamycin for the purpose to extend shelf life of fruit and it had been reported that compared with uncoated fresh fruits, the shelf life of fresh strawberry had been increased (Duran et al., 2016).

\section{Volatile Substances and Essential Oils}

Volatile antimicrobial agent addition into sachet and pads is another application of active packaging technology which gets attention due to no need for contact between food and antimicrobial agent resulting no impact the sensorial properties of food product (Kapetanakou, Agathaggelou, \& Skandamis, 2014). The volatile antimicrobial substances can be produced mainly from natural plants such as essential oils or it may be foodgrade ethanol.

Essential oils extracted from plants have become popular due to their natural sources such as rosemary, lemongrass, ginger and curcumin extracts and their non-toxicity, inherent antimicrobial and antioxidant activities (Klangmuang \& Sothornvit, 2016; O' Callaghan \& Kerry, 2014; Takala, Vu, Salmieri, Khan, \& Lacroix, 2013; Wang et al., 2017). Herbal oils generally are considered to be replacement of organic acids due to their antibacterial, antifungal and antioxidant properties (Klangmuang \& Sothornvit, 2016).

The most important limitation of usage of essential oils to produce active films is their volatility and thermal degradation when incorporated during the mechanical processing of the polymeric films (Mulla et al., 2017). However, Kuorwel, Cran, Sonneveld, Miltz, and Bigger (2013) have impregnated carvacrol, linalool and thymol with 


\section{Food and Health, 4(1): 63-79 (2018)}

\section{Journal abbreviation: Food Health}

hydroxypropyl methylcellulose (HPMC) film using both coating and solution- heat pressing techniques. They have reported that diffusion coefficients of heat pressed film much higher than film produced coating techniques. They have concluded that this antimicrobial agents show a potential for use in antimicrobial packaging materials produced using this two methods.

Klangmuang and Sothornvit (2016) had produced antimicrobial active edible films containing Thai essential oil and reported the films were effective against to $E$. coli (gram negative) and $S$. aureus (gram positive) (Table 1). Same as Thai, another effective natural spice on the $E$. coli and $S$. aureus is curcumin which is extracted from Curcuma longa and have anti-inflammation, antiviral, and antioxidant activities (Wang et al., 2017).

Food-grade alcohol can be used as antimicrobial sachets into food packaging system. Kapetanakou et al. (2014) had developed an packaging system to observe the effect of some commercial alcoholic beverages (whisky, brandy, tsipouro, raki, and ouzo) vapors on microbial, physicochemical, and sensory profile of pork meat stored in different modified atmosphere packaging (MAP) conditions. It had been reported that vapor action of alcoholic beverages in combination with MAP may offer a promising, antimicrobial packaging application for extending the shelf-life of pork meat (Kapetanakou et al., 2014).

\section{Other Antimicrobial Substances}

Metals: Among the antimicrobials used in active packaging technology, silver takes the attention mostly because of its suitable technological properties and broad antimicrobial spectrum. The usage of silver as antimicrobial has gone as far as to the ancient times. The historic source reported that silver spoon used in milk to prolong shelf life (Duncan, 2011). From past to today, the silver application has reached a wide range area. For example, silver has been preferred as antimicrobial agent into water which will be consumed by astronauts and must be stored very long time. Moreover, in 2009, FDA has permitted direct addition of silver nitrate to water if not to exceed $17 \mu \mathrm{g} / \mathrm{kg}$ (Duncan, 2011).

Although there is no evidence for carcinogenic and mutagenic effect of silver, since some researchers claimed that silver can toxic for human cells, alter usual function of mitochondria and accelerate reactive oxygen generation, the usage of silver in food production is in question
(Echegoyen \& Nerin, 2013; Kumar \& Munstedt, 2005; Song, Li, Lin, Wu, \& Chen, 2011). Direct usage of silver or to be in contact with food in some countries is forbidden; EFSA says that silver should be in list of suspicious additives. On the contrary, in USA it is allowed and described as GRAS by FDA (Azlin-Hasim, Cruz-Romero, Morris, Cummins, \& Kerry, 2015).

Besides to the other antimicrobials which have antimicrobial activity in specific microorganism classes, silver has broad spectrum and inhibit to unlimited strains of bacteria, fungi, algae and possibly some viruses (Duncan, 2011; Rhim, Wang, \& Hong, 2013). Since silver is easily incorporated into many materials, the application to the packaging technology has been expanded in a short time especially in Japan (Duncan, 2011). Silver can be applied to the food industry in three forms; (1) direct addition of silver, (2) the form of silver nitrate (generally direct addition), and (3) the form of silver substituted zeolite. Silver substituted zeolite is mostly preferred for films for the reason that capability of slow release of silver to food surface (Kaba \& Duyar, 2008).

The mechanism of silver against the microorganism can be explained via following ways: (1) by means of binding to sulfhydryl or disulfide functional groups on the surface of membrane protein, (2) disturbing DNA replication, (3) oxidative stress through the catalysis of reactive oxygen spices formation (Duncan, 2011). However, it has been accepted that the mechanism of silver is mainly based on electrostatic interaction The negative charge of silver ion can be adsorbed by the microorganism cell membrane and silver inactivate the enzymes in cytoplasm by binding them (Kaba \& Duyar, 2008). Silver ions react with thiol group of enzymes and inactivate them, resulting in ending of DNA replication (Matsumura, Yoshikata, Kunisaki, \& Tsuchido, 2003).

The effect of silver packaging films on chicken breast meat quality was studied (Matsumura et al., 2003), the meats were wrapped with Ag films (5\%-LDPE) and stored at cold condition during storage up to 21 days. It was reported that the migration concentration of $\mathrm{Ag}$ on surface was enough to inhibit microorganism and at the same time it was below from maximum limit allowed by legislation $(25 \mathrm{mg} / \mathrm{kg})$ for protection of quality of the meat at the end of the storage period.

There are plenty of studies focused on antimicrobial packaging interested in silver especially in 


\section{Food and Health, 4(1): 63-79 (2018)}

\section{Journal abbreviation: Food Health}

last five years (Table 1). Silver can be incorporated into both biodegradable and petroleum polymer packaging systems. Currently, there are commercial antimicrobial packaging systems with silver for instance AgIon and Noavaron in the packaging marketing.

Copper can destroy microorganisms and viruses; however it is not generally used in active packaging technology since it is regarded as toxic to human body (Rhim, Park, \& Ha, 2013). Metal oxides such as titanium dioxide $\left(\mathrm{TiO}_{2}\right)$, zinc oxide $(\mathrm{ZnO})$ and magnesium oxide $(\mathrm{MgO})$ are another strong antimicrobial groups and used in food packaging technology because of high stability compared with organic acids. $\mathrm{TiO}_{2}$ is an inert, non-toxic, inexpensive antimicrobial agent with activity against broad spectrum of microorganism. In order to activate this metallic oxide, ultraviolet as an excitation source is needed therefore the antimicrobial activity and photocatalyst of $\mathrm{TiO}_{2}$ are enhances with metallic ions such as $\mathrm{Fe}^{+3}, \mathrm{Ag}$ or $\mathrm{SnO}_{2}$ (Rhim, Park, et al., 2013).

Chitosan: Chitosan is a functional natural polymer that is non-toxic, biodegradable, has antimicrobial properties and is the most abundant carbohydrate in nature after cellulose, its linear polymer chain contains (1-4)-2-acetoamido-2-deoxy- $\beta$-Dglucose. The polymer consists of an aminoglucopyranan of $\mathrm{N}$-acethylglucosamine and glucoside residues. Chitosan is obtained by chitin, which occurs inherently the cuticle of arthropods and endoskeletons of cephalopods. The process steps mostly involve deproteinization, deminarilization and chemical deacetylation (Dotto, Buriol, \& Pinto, 2014; Dutta, Tripathi, Mehrotra, \& Dutta, 2009; El-Saharty \& Bary, 2002; Siripatrawan \& Noipha, 2012; Yoshida, Bastos, \& Franco, 2010).

Because of inherent antimicrobial activity and good film forming ability of chitosan, it has a potential to be used in biodegradable active films (Siripatrawan \& Vitchayakitti, 2016). Chitosan has been used as antimicrobial substances in films owing to its effectiveness of inhibiting the growth of not just gram negative but also gram positive bacteria alongside the yeast and molds. The activity of chitosan comes from its positive charge so it affects microorganisms electrostatically: chitosan can incorporate the macromolecules present in cell membrane cause linkages. Ouattara, Simard, Piette, Bégin, and Holley (2000) have prepared the films containing chitosan and observed the its inhibition ability against lactic acid bacteria, Enter- obacteriaceae and Serratia liquefaciens inoculated on meats (Ouattara et al., 2000). It had been claimed that while lactic acid bacteria had not been affected, the growth of Enterobacteriaceae and Serratia liquefaciens had been delayed or completely inhibited. The activity of chitosan is affected by several factors that are $\mathrm{pH}$ of medium, molecular weight and the degree of deacetylation of chitosan. For example, at low $\mathrm{pH}$, chitosan is more effective due to "hurdle" effect (Aider, 2010; Dutta et al., 2009). The molecular weight of chitosan is another important factor in terms of antimicrobial effects. The chitosan derivative having low molecular weight is more effective because that chitosan can enter the microbial cell more easily than its high molecule weight derivate (CruzRomero et al., 2013; O' Callaghan \& Kerry, 2014).

Soysal et al. (2015) had stored chicken drumstick wrapped with multilayer LDPE active films containing chitosan at $5^{\circ} \mathrm{C}$ during 6 days and they reported that efficiency in inhibiting total aerobic mesophilic bacteria (APC), total coliforms and total molds and yeasts had been evaluated by comparison with control bag (LDPE-polyamideLDPE). APC counts of samples packed $1.03 \mathrm{log}$ had been lower than those of samples packed in control bags (Soysal et al., 2015). Also, Guo, Jin, Wang, Scullen, and Sommers (2014) have produced poly(-lactic) acid (PLA) films coated chitosan. They have observed that this antimicrobial packaging system can inhibit the growth of Listeria innocua from meat surface up to $0.8 \mathrm{log}$.

Others: There are many different antimicrobial agents used in antimicrobial packaging system such as lauric acid esters, cinnamaldehyde or lysozyme (Table 1). And also antimicrobial agent can be extracted from well-known plants such as green tea extracts. Due to polyphenol content of green tea, it can decelerate growth of Listeria monocytogenes, Escherichia coli O157:H7, Salmonella typhimurium, Staphylococcus aureus, Shigella flexneri, and Vibrio cholera (Siripatrawan \& Noipha, 2012). Siripatrawan and Noipha (2012) have reported that edible active film containing green tea extract have successful on microbial growth inhibition and prolonged shelf life of pork sausages. 


\section{Food and Health, 4(1): 63-79 (2018)}

Journal abbreviation: Food Health

Table 1. Recent antimicrobial active packaging studies

\begin{tabular}{|c|c|c|c|c|c|c|}
\hline $\begin{array}{l}\text { Antimicrobial } \\
\text { Type }\end{array}$ & $\begin{array}{l}\text { Antimicrobial } \\
\text { name }\end{array}$ & Polymer/Carrier & $\begin{array}{l}\text { Aim of the } \\
\text { incorporation }\end{array}$ & Applied food system & $\begin{array}{l}\text { Target } \\
\text { microorganism }\end{array}$ & Reference \\
\hline \multirow[t]{6}{*}{ Organic acids } & Potassium sorbate & LLDPE & $\begin{array}{l}\text {-Diffusion into } \\
\text { food simulant } \\
\text {-Antimicrobial } \\
\text { activity }\end{array}$ & Food simulant :acetate buffer $\mathrm{pH} 4.2$ & Yeasts & Kuplennik et al. (2015) \\
\hline & & Starch-clay composite & $\begin{array}{l}\text {-Diffusion into } \\
\text { food simulant } \\
\text {-Antimicrobial } \\
\text { activity }\end{array}$ & Semisolid agar simulant & Aspergillus niger & Barzegar et al. (2014) \\
\hline & & Chitosan film & $\begin{array}{l}\text {-Diffusion into } \\
\text { food simulant }\end{array}$ & Water & -- & Yoshida et al. (2010) \\
\hline & & Whey film & $\begin{array}{l}\text {-Diffusion into } \\
\text { food simulant }\end{array}$ & Water-glycerol system & -- & Ozdemir and Floros (2001) \\
\hline & Sorbic acid & LDPE & $\begin{array}{l}\text {-Antimicrobial } \\
\text { activity }\end{array}$ & Pastry dough & $\begin{array}{l}\text {-Aerobic mesophilic count } \\
\text {-psychrophilic } \\
\text {-Stapylococcus aureus } \\
\text {-fungus } \\
\text {-yeast }\end{array}$ & Silveira et al. (2007) \\
\hline & & PVA & $\begin{array}{l}\text { Antimicrobial } \\
\text { activity }\end{array}$ & Gouda cheese & $\begin{array}{l}\text {-Listeria monocytogenes } \\
\text {-Saccharomyces cerevisiae } \\
\text {-Escherichia coli }\end{array}$ & Hauser and Wunderlich (2011) \\
\hline \multirow[t]{4}{*}{ Bacteriocin } & Nisin & HPMC film & $\begin{array}{l}\text { Diffusion into } \\
\text { food simulant }\end{array}$ & Agarose gel & -- & Sebti et al. (2003) \\
\hline & & $\begin{array}{l}\text {-Sodium caseinate } \\
\text {-Poly (lactic) acid (PLA) } \\
\text {-Chitosan }\end{array}$ & $\begin{array}{l}\text {-Diffusion into } \\
\text { food simulant } \\
\text {-Antimicrobial } \\
\text { activity }\end{array}$ & Water- ethanol solution & $\begin{array}{l}\text {-Listeria monocytogenes } \\
\text {-Staphylococcus aureus }\end{array}$ & Imran et al. (2014) \\
\hline & & PLA & $\begin{array}{l}\text { Antimicrobial } \\
\text { activity }\end{array}$ & Deli turkey meat & Listeria innocua & Guo et al. (2014) \\
\hline & & $\begin{array}{l}\text {-Corn zein } \\
\text {-Wheat gluten }\end{array}$ & $\begin{array}{l}\text {-Diffusion into } \\
\text { food simulant } \\
\text {-Antimicrobial } \\
\text { activity }\end{array}$ & Water & Lactobacillus plantarum & Teerakarn et al. (2002) \\
\hline
\end{tabular}




\section{Food and Health, 4(1): 63-79 (2018)}

Journal abbreviation: Food Health

\begin{tabular}{|c|c|c|c|c|c|c|}
\hline & & Chitosan/PVA & $\begin{array}{l}\text {-Diffusion into } \\
\text { food simulant } \\
\text {-Antimicrobial } \\
\text { activity }\end{array}$ & Water & Stapylococcus aureus & Wang et al. (2015) \\
\hline & & Starch based film & $\begin{array}{l}\text { Antimicrobial } \\
\text { activity }\end{array}$ & -- & Gram negative cocci & Bhatia and Bharti (2015) \\
\hline & & LDPE & $\begin{array}{l}\text {-Diffusion into } \\
\text { food simulant } \\
\text {-Antimicrobial } \\
\text { activity }\end{array}$ & $\begin{array}{l}\text {-Water } \\
\text {-PBS system }\end{array}$ & Micrococcus luteus & Mauriello et al. (2005) \\
\hline & & $\begin{array}{l}\text { Poly(butylene adipate- } \\
\text { co-terephthalate) }\end{array}$ & $\begin{array}{l}\text { Diffusion into } \\
\text { food simulant }\end{array}$ & Water & -- & $\begin{array}{l}\text { L. Bastarrachea, Dhawan, Sablani, and } \\
\text { Powers (2010) }\end{array}$ \\
\hline \multirow[t]{7}{*}{$\begin{array}{l}\text { Natural Essen- } \\
\text { tial oils }\end{array}$} & Carvacrol & Starch based & $\begin{array}{l}\text { Diffusion into } \\
\text { food simulant }\end{array}$ & Fatty-food simulant & -- & Kuorwel et al. (2013) \\
\hline & & LDPE/Clay & $\begin{array}{l}\text { Antimicrobial } \\
\text { activity }\end{array}$ & -- & $\begin{array}{l}\text {-Escherichia coli } \\
\text {-Listeria innocua } \\
\text {-Alternaria alternata }\end{array}$ & Shemesh et al. (2015) \\
\hline & & LDPE & $\begin{array}{l}\text { Diffusion into } \\
\text { food simulant }\end{array}$ & Food Simulants: class B & -- & $\begin{array}{l}\text { Campos-Requena, Rivas, Perez, } \\
\text { Garrido-Miranda, and Pereira (2015) }\end{array}$ \\
\hline & $\begin{array}{l}\text {-Linalool } \\
\text {-Thymol }\end{array}$ & Starch based & $\begin{array}{l}\text { Diffusion into } \\
\text { food simulant }\end{array}$ & Fatty-food simulant & -- & Kuorwel et al. (2013) \\
\hline & Clove & LLDPE & $\begin{array}{l}\text { Antimicrobial } \\
\text { activity }\end{array}$ & Chicken & $\begin{array}{l}\text {-Salmonella enterica } \\
\text {-Listeria monocytogenes }\end{array}$ & Mulla et al. (2017) \\
\hline & $\begin{array}{l}\text {-Ginger } \\
\text {-Fingerroot } \\
\text {-Plai }\end{array}$ & HPMC & $\begin{array}{l}\text { Antimicrobial } \\
\text { activity }\end{array}$ & -- & $\begin{array}{l}\text {-Stapylococcus aureus } \\
\text { - Escherichia coli }\end{array}$ & Klangmuang and Sothornvit (2016) \\
\hline & $\begin{array}{l}\text { Allyl iso- } \\
\text { thiocyanate }\end{array}$ & PLA & -- & -- & -- & Kurek et al. (2017) \\
\hline
\end{tabular}




\section{Food and Health, 4(1): 63-79 (2018)}

Journal abbreviation: Food Health

\begin{tabular}{|c|c|c|c|c|c|c|}
\hline & $\begin{array}{l}\text {-Rosemary } \\
\text { +Asian spices } \\
\text {-Rosemary } \\
\text { +İtalian spices }\end{array}$ & MC & $\begin{array}{l}\text { Antimicrobial } \\
\text { activity }\end{array}$ & Broccoli & $\begin{array}{l}\text {-Listeria monocytogenes } \\
\text { - Escherichia coli } \\
\text {-Salmonella }\end{array}$ & Takala et al. (2013) \\
\hline \multirow[t]{9}{*}{ Metals } & \multirow[t]{7}{*}{ Silver } & $\begin{array}{l}\text {-LDPE } \\
\text {-PP } \\
\text {-polyolefin }\end{array}$ & -- & -- & -- & Echegoyen and Nerin (2013) \\
\hline & & Composite film types & $\begin{array}{l}\text { Antimicrobial } \\
\text { activity }\end{array}$ & -- & $\begin{array}{l}\text { Gram negative and positive } \\
\text { bacteria }\end{array}$ & Rhim, Wang, et al. (2013) \\
\hline & & Cellulose based & $\begin{array}{l}\text { Antimicrobial } \\
\text { activity }\end{array}$ & -- & $\begin{array}{l}\text {-Escherichia coli } \\
\text {-Staphylococcus aureus }\end{array}$ & $\begin{array}{l}\text { de Moura, Mattoso, and Zucolotto } \\
\text { (2012) }\end{array}$ \\
\hline & & LDPE & $\begin{array}{l}\text { Antimicrobial } \\
\text { activity }\end{array}$ & Chicken breast & $\begin{array}{l}\text {-Total viable count } \\
\text {-psychrophilic bacteria } \\
\text {-Pseudomonas spp. } \\
\text {-Brochothrix thermosphacta } \\
\text {-lactic acid bacteria } \\
\text {-total coliforms } \\
\text {-Escherichia coli }\end{array}$ & Azlin-Hasim et al. (2015) \\
\hline & & $\begin{array}{l}\text { Commercial plastic con- } \\
\text { tainers }\end{array}$ & $\begin{array}{l}\text { Diffusion into } \\
\text { food simulant }\end{array}$ & $\begin{array}{l}\text { Simulant recommended by Euro- } \\
\text { pean commission } 97 / 48 / E C\end{array}$ & -- & von Goetz et al. (2013) \\
\hline & & PLA & $\begin{array}{l}\text {-Diffusion into } \\
\text { food simulant } \\
\text {-Antimicrobial } \\
\text { activity }\end{array}$ & $\mathrm{HNO}_{3}$ solution & Salmonella spp. & $\begin{array}{l}\text { Busolo, Fernandez, Ocio, and Lagaron } \\
\text { (2010) }\end{array}$ \\
\hline & & Polyamide & $\begin{array}{l}\text { Diffusion into } \\
\text { food simulant }\end{array}$ & -- & -- & Kumar and Munstedt (2005) \\
\hline & \multirow[t]{2}{*}{ Silver-zinc } & Polyamide & $\begin{array}{l}\text { Antimicrobial } \\
\text { activity }\end{array}$ & Chicken and beef sausages & $\begin{array}{l}\text {-Salmonella } \\
\text {-Pseudomonas } \\
\text {-Penicillium } \\
\text {-Listeria }\end{array}$ & Patiño et al. (2014) \\
\hline & & LDPE & $\begin{array}{l}\text { Antimicrobial } \\
\text { activity }\end{array}$ & Chicken breast & $\begin{array}{l}\text {-Listeria } \\
\text {-Pseudomonas } \\
\text {-Escherichia coli }\end{array}$ & $\begin{array}{l}\text { Panea, Ripoll, González, Fernández- } \\
\text { Cuello, and Albertí (2014) }\end{array}$ \\
\hline
\end{tabular}




\section{Food and Health, 4(1): 63-79 (2018)}

\section{Journal abbreviation: Food Health}

\begin{tabular}{|c|c|c|c|c|c|c|}
\hline \\
\hline & $\begin{array}{l}\text { Silver-Titanium } \\
\text { dioxide }\end{array}$ & PLA & $\begin{array}{l}\text {-Diffusion into } \\
\text { food simulant } \\
\text {-Antimicrobial } \\
\text { activity }\end{array}$ & $\begin{array}{l}\text { Simulant recommended by Euro- } \\
\text { pean commission } 85 / 572 / \text { EEC }\end{array}$ & $\begin{array}{l}\text { - Escherichia coli } \\
\text {-Listeria monocytogenes }\end{array}$ & Li et al. (2017) \\
\hline \multirow[t]{2}{*}{ Polysaccharide } & Chitosan & Pectin based & -- & -- & -- & $\begin{array}{l}\text { Lorevice, Otoni, de Moura, and Mattoso } \\
\text { (2016) }\end{array}$ \\
\hline & & PLA & $\begin{array}{l}\text { Antimicrobial } \\
\text { activity }\end{array}$ & Turkey meat & Listeria innocue & Guo et al. (2014) \\
\hline \multirow[t]{5}{*}{$\begin{array}{l}\text { Other antimi- } \\
\text { crobial agents }\end{array}$} & Lauric acid ester & PLA & $\begin{array}{l}\text { Antimicrobial } \\
\text { activity }\end{array}$ & Turkey meat & Listeria innocue & Guo et al. (2014) \\
\hline & & Chitosan & -- & -- & $\begin{array}{l}\text {-Lactobacillus sakei } \\
\text {-Serratia liquefaciens } \\
\text {-Enterobacteriaceae } \\
\text {-Total LAB }\end{array}$ & Ouattara et al. (2000) \\
\hline & Cinnamaldehyde & Chitosan & -- & -- & $\begin{array}{l}\text { Lactobacillus sakei } \\
\text {-Serratia liquefaciens } \\
\text {-Enterobacteriaceae } \\
\text {-Total LAB }\end{array}$ & Ouattara et al. (2000) \\
\hline & $\begin{array}{l}\text {-Lysozyme } \\
\text {-Ethylenedia- } \\
\text { mine-tetraacetate }\end{array}$ & Starch based film & $\begin{array}{l}\text { Antimicrobial } \\
\text { activity }\end{array}$ & -- & Gram negative cocci & Bhatia and Bharti (2015) \\
\hline & Green tea extract & Chitosan & $\begin{array}{l}\text { Antimicrobial } \\
\text { activity }\end{array}$ & Pork sausages & $\begin{array}{l}\text {-Total viable count } \\
\text {-Yeast } \\
\text {-Mold }\end{array}$ & Siripatrawan and Noipha (2012) \\
\hline
\end{tabular}




\section{Food and Health, 4(1): 63-79 (2018)}

\section{Journal abbreviation: Food Health}

\section{Influence of Antimicrobial Substances on Engineering Properties of Films}

Assessing engineering features of packaging material is the first step for designing a packaging material for foods. The engineering properties of films are tensile and barrier properties. While tensile values such as tensile strength, elastic modulus and elongation at break are important for measuring durability of polymers under a force, knowing barrier properties of a packaging material such as water vapor and oxygen permeability is crucial in terms of controlling food quality changes during storage. These properties can be affected by addition of antimicrobial which are mainly dependent on the molecular weight of antimicrobial agents, the interaction between polymer and antimicrobials (Bastarrachea, Dhawan, \& Sablani, 2011). Synthetic polymers include polyethylene (PE), polypropylene (PP), polystyrene (PS), ethylene-vinyl acetate (EVA), polyvinyl chloride (PVC), polyamide (PA) and polybutyrate (PBAT) have been preferred mostly in antimicrobial active packaging technology along with some cellulose or gelatin based biopolymers.

The changes in mechanical properties after addition of antimicrobial into film blend are mainly dependent on the solubility of antimicrobial into blend. Generally, if antimicrobial agents can corporate with film matrix well, the tensile strength and elongation at break either remain unchanged or change positively (Clarke et al., 2016; Pires et al., 2008).

Another important factor is the incorporation method of antimicrobial into polymer, such as lamination, blending using different techniques, spraying onto film surface (Bastarrachea et al., 2011). It had been reported that the mechanical properties were not dependent on deposition methods of silver nanoparticles into multilayer PE films via three deposition methods that were lamination and extrusion, blending though sonication and solution-casting method, and spraying (Sanchez-Valdes, Ortega-Ortiz, Valle, MedellinRodriguez, \& Guedea-Miranda, 2009). Moreover Pires et al. (2008) had stated that the incorporation of antimicrobial compounds, nisin and natamycin, had led to decrease the resistance and elongation of the films and caused changes in their molecular conformation. For example, the addition of nisin into cellulose derivative polymers had affected the elongation at break values adversely and decreased more than four times compared with control films (Pires et al., 2008).
The addition of antimicrobials into film blends may affect the mechanical features in good ways. In a study, commercial antimicrobial combinations containing sodium citrate, sodium metabisulfite, citric, malic acids etc. had been corporate with gelatin based films and resulted improvement in tensile strength and elongation break due to interfering of antimicrobials with film cross-linkages (Clarke et al., 2016).

Gas barrier properties is crucial for food packaging technology since insufficient barrier features can lead to acceleration of food spoilage mechanism such as lipid oxidation, microbial growth or/ and textural changes (Kashiri et al., 2016). Gas barrier properties can be altered by addition of antimicrobial and it is not always negative. If polymer films incorporated with a hydrophobic antimicrobial agent, water vapor permeability property may decrease which is a desirable result for film production, yet it should not be generalized. On the other hand, antimicrobial substances can create pinhole though film matrix due to its solubility into film blend and cause to increase gas permeability. For example addition of silver to the films can change the physical properties; Rhim, Park, et al. (2013) reported that silver incorporation had led to significant increase in water vapor barrier properties and surface hydrophobicity (Rhim, Wang, et al., 2013). Also, in another research it was notified that the addition of potassium sorbate in films, it has caused to change water permeability and elongation positively but not in tensile strength (Barzegar, Azizi, Barzegar, \& Hamidi-Esfahani, 2014) indicating the effect of antimicrobial type used in film on physical properties of films.

Bierhalz, da Silva, de Sousa, Braga, and Kieckbusch (2013) had reported that nisin and natamycin had been added into film matrix resulting in enhancing the water vapor permeability of the films since it might cause micro or macro heterogeneities in polymer structure due to the presence of antimicrobial's (Bierhalz et al., 2013). Unlike tensile properties, it was reported that the loading method of antimicrobial in active packaging films influence the barrier properties of the films. The new loading methods such as immersion or supercritical solvent impregnation help to incorporate especially hydrophobic antimicrobial in film homogeneously resulting good barrier properties of films (Bierhalz et al., 2013).

The final barrier properties of improved films were dependent on type of antimicrobial added 


\section{Food and Health, 4(1): 63-79 (2018)}

\section{Journal abbreviation: Food Health}

and polymer structure of the film. For designing an antimicrobial active packaging this point was also investigated due improper packaging material with low mechanical property may not be helpful for packaging purposes.

\section{Conclusion}

Antimicrobial active packaging technology has gained great interest because of the high potential to inhibit microbial growth without addition a chemical in food system or minimizing concentration of the chemical used for. Up to now, there are plenty of studies revealed that antimicrobial films help to improve of shelf life of food products. In literature, there is a tendency to look for new natural and/or harmless antimicrobial constituent that are more efficient and durable than antimicrobial used currently in active packaging technology such as sorbic acid. Moreover, biopolymers as antimicrobial carrier has also get great interest due to environmental concerns. However there are some limitations to use biopolymers such as degradation rates under various conditions, changes in mechanical properties and potential microbial growth. On the other hand, petroleum-based plastic materials are cheap, convenient and have excellent physicochemical properties that are why plastic materials have been widely used since the middle of twenty century. Therefore, studies must be increased to develop bio-composite for food packaging films with good mechanical, barrier and thermal properties.

During designing antimicrobial active films some analysis such as antimicrobial efficiency, the mechanical and barrier features of films should be performed since even small quantities of corresponding antimicrobial can alter film properties in unpredictable ways. This information is needed to understand practicability of designed film into industrial scale.

\section{References}

Aider, M. (2010). Chitosan application for active bio-based films production and potential in the food industry: Review. Lwt-Food Science and Technology, 43(6), 837-842.

Appendini, P., \& Hotchkiss, J. H. (2002). Review of antimicrobial food packaging. Innovative Food Science \& Emerging Technologies, 3(2), 113-126.

Azlin-Hasim, S., Cruz-Romero, M. C., Morris, M. A., Cummins, E., \& Kerry, J. P. (2015).
Effects of a combination of antimicrobial silver low density polyethylene nanocomposite films and modified atmosphere packaging on the shelf life of chicken breast fillets. Food Packaging and Shelf Life, 4, 26-35.

Barzegar, H., Azizi, M. H., Barzegar, M., \& Hamidi-Esfahani, Z. (2014). Effect of potassium sorbate on antimicrobial and physical properties of starch-clay nanocomposite films. Carbohydrate Polymers, 110, 26-31.

Bastarrachea, L., Dhawan, S., \& Sablani, S. S. (2011). Engineering Properties of PolymericBased Antimicrobial Films for Food Packaging: A Review. Food Engineering Reviews, 3(2), 79-93.

Bastarrachea, L., Dhawan, S., Sablani, S. S., \& Powers, J. (2010). Release kinetics of nisin from biodegradable poly(butylene adipateco-terephthalate) films into water. Journal of Food Engineering, 100(1), 93-101.

Bhatia, S., \& Bharti, A. (2015). Evaluating the antimicrobial activity of Nisin, Lysozyme and Ethylenediaminetetraacetate incorporated in starch based active food packaging film. Journal of Food Science and Technology-Mysore, 52(6), 3504-3512.

Bierhalz, A. C. K., da Silva, M. A., de Sousa, H. C., Braga, M. E. M., \& Kieckbusch, T. G. (2013). Influence of natamycin loading methods on the physical characteristics of alginate active films. The Journal of Supercritical Fluids, 76, 74-82.

Bierhalz, A. C. K., da Silva, M. A., \& Kieckbusch, T. G. (2012). Natamycin release from alginate/pectin films for food packaging applications. Journal of Food Engineering, 110(1), 18-25.

Branen, A. L., Davidson, P. M., Salminen, S., \& Thorngate, J. (2001). Food additives: CRC Press.

Brennan, J. G., \& Grandison, A. S. (2012). Food processing handbook: John Wiley \& Sons.

Busolo, M. A., Fernandez, P., Ocio, M. J., \& Lagaron, J. M. (2010). Novel silver-based nanoclay as an antimicrobial in polylactic acid food packaging coatings. Food Additives \& Contaminants: Part A, 27(11), 1617-1626. 


\section{Food and Health, 4(1): 63-79 (2018)}

\section{Journal abbreviation: Food Health}

Campos-Requena, V. H., Rivas, B. L., Perez, M. A., Garrido-Miranda, K. A., \& Pereira, E. D. (2015). Polymer/clay nanocomposite films as active packaging material: Modeling of antimicrobial release. European Polymer Journal, 71, 461-475.

Clarke, D., Molinaro, S., Tyuftin, A., Bolton, D., Fanning, S., \& Kerry, J. P. (2016). Incorporation of commercially-derived antimicrobials into gelatin-based films and assessment of their antimicrobial activity and impact on physical film properties. Food Control, 64, 202-211.

Cruz-Romero, M. C., Murphy, T., Morris, M., Cummins, E., \& Kerry, J. P. (2013). Antimicrobial activity of chitosan, organic acids and nano-sized solubilisates for potential use in smart antimicrobially-active packaging for potential food applications. Food Control, 34(2), 393-397.

de Moura, M. R., Mattoso, L. H. C., \& Zucolotto, V. (2012). Development of cellulose-based bactericidal nanocomposites containing silver nanoparticles and their use as active food packaging. Journal of Food Engineering, 109(3), 520-524.

Dobias, J., Chudackova, K., Voldrich, M., \& Marek, M. (2000). Properties of polyethylene films with incorporated benzoic anhydride and/or ethyl and propyl esters of 4hydroxybenzoic acid and their suitability for food packaging. Food Additives and Contaminants, 17(12), 1047-1053.

Dotto, G. L., Buriol, C., \& Pinto, L. A. A. (2014). Diffusional mass transfer model for the adsorption of food dyes on chitosan films. Chemical Engineering Research and Design, 92(11),2324-2332.

Duncan, T. V. (2011). Applications of nanotechnology in food packaging and food safety: barrier materials, antimicrobials and sensors. Journal of Colloid and Interface Science, 363(1), 1-24.

Duran, M., Aday, M. S., Zorba, N. N. D., Temizkan, R., Buyukcan, M. B., \& Caner, C. (2016). Potential of antimicrobial active packaging 'containing natamycin, nisin, pomegranate and grape seed extract in chitosan coating' to extend shelf life of fresh strawberry. Food and Bioproducts Processing, 98, 354-363.
Dutta, P. K., Tripathi, S., Mehrotra, G. K., \& Dutta, J. (2009). Perspectives for chitosan based antimicrobial films in food applications. Food Chemistry, 114(4), 11731182.

Echegoyen, Y., \& Nerin, C. (2013). Nanoparticle release from nano-silver antimicrobial food containers. Food and Chemical Toxicology, 62, 16-22.

El-Saharty, Y. S., \& Bary, A. A. (2002). Highperformance liquid chromatographic determination of neutraceuticals, glucosamine sulphate and chitosan, in raw materials and dosage forms. Analytica Chimica Acta, 462(1), 125-131.

Fucinos, C., Miguez, M., Cerqueira, M. A., Costa, M. J., Vicente, A. A., Rua, M. L., \& Pastrana, L. M. (2015). Functional Characterisation and Antimicrobial Efficiency Assessment of Smart Nanohydrogels Containing Natamycin Incorporated into Polysaccharide-Based Films. Food and Bioprocess Technology, 8(7), 1430-1441.

Guo, M., Jin, T. Z., Wang, L., Scullen, O. J., \& Sommers, C. H. (2014). Antimicrobial films and coatings for inactivation of Listeria innocua on ready-to-eat deli turkey meat. Food Control, 40, 64-70.

Hauser, C., \& Wunderlich, J. (2011). Antimicrobial packaging films with a sorbic acid based coating. Procedia Food Science, 1, 197-202.

Imran, M., Klouj, A., Revol-Junelles, A.-M., \& Desobry, S. (2014). Controlled release of nisin from HPMC, sodium caseinate, polylactic acid and chitosan for active packaging applications. Journal of Food Engineering, 143, 178-185.

Kaba, N., \& Duyar, H. A. (2008). Antimikrobiyal Paketleme. Ege Üniversitesi Su Ürünleri Dergisi, 25(2), 181-185.

Kapetanakou, A. E., Agathaggelou, E. I., \& Skandamis, P. N. (2014). Storage of pork meat under modified atmospheres containing vapors from commercial alcoholic beverages. International Journal of Food Microbiology, $178,65-75$.

Kashiri, M., Cerisuelo, J. P., Dominguez, I., Lopez-Carballo, G., Hernandez-Munoz, P., 


\section{Food and Health, 4(1): 63-79 (2018)}

\section{Journal abbreviation: Food Health}

\& Gavara, R. (2016). Novel antimicrobial zein film for controlled release of lauroyl arginate (LAE). Food Hydrocolloids, 61, 547-554.

Klangmuang, P., \& Sothornvit, R. (2016). Barrier properties, mechanical properties and antimicrobial activity of hydroxypropyl methylcellulose-based nanocomposite films incorporated with Thai essential oils. Food Hydrocolloids, 61, 609-616.

Kumar, R., \& Munstedt, H. (2005). Silver ion release from antimicrobial polyamide/silver composites. Biomaterials, 26(14), 20812088.

Kuorwel, K. K., Cran, M. J., Sonneveld, K., Miltz, J., \& Bigger, S. W. (2013). Migration of antimicrobial agents from starch-based films into a food simulant. LWT - Food Science and Technology, 50(2), 432-438.

Kuplennik, N., Tchoudakov, R., Zelas, Z. B. B., Sadovski, A., Fishman, A., \& Narkis, M. (2015). Antimicrobial packaging based on linear low-density polyethylene compounded with potassium sorbate. Lwt-Food Science and Technology, 62(1), 278-286.

Kurek, M., Laridon, Y., Torrieri, E., Guillard, V., Pant, A., Stramm, C., . . . Guillaume, C. (2017). A mathematical model for tailoring antimicrobial packaging material containing encapsulated volatile compounds. Innovative Food Science \& Emerging Technologies, 42, 64-72.

Lantano, C., Alfieri, I., Cavazza, A., Corradini, C., Lorenzi, A., Zucchetto, N., \& Montenero, A. (2014). Natamycin based sol-gel antimicrobial coatings on polylactic acid films for food packaging. Food Chemistry, $165,342-347$.

Li, W., Zhang, C., Chi, H., Li, L., Lan, T., Han, P., . . Qin, Y. (2017). Development of Antimicrobial Packaging Film Made from Poly (Lactic Acid) Incorporating Titanium Dioxide and Silver Nanoparticles. Molecules, 22(7).

Liu, W., \& Hansen, J. N. (1990). Some chemical and physical properties of nisin, a smallprotein antibiotic produced by Lactococcus lactis. Applied and Environmental Microbiology, 56(8), 2551-2558.
Lorevice, M. V., Otoni, C. G., de Moura, M. R., \& Mattoso, L. H. C. (2016). Chitosan nanoparticles on the improvement of thermal, barrier, and mechanical properties of highand low-methyl pectin films. Food Hydrocolloids, 52, 732-740.

Matsumura, Y., Yoshikata, K., Kunisaki, S. i., \& Tsuchido, T. (2003). Mode of Bactericidal Action of Silver Zeolite and Its Comparison with That of Silver Nitrate. Applied and Environmental Microbiology, 69(7), 42784281.

Mauriello, G., De Luca, E., La Storia, A., Villani, F., \& Ercolini, D. (2005). Antimicrobial activity of a nisin-activated plastic film for food packaging. Letters in Applied Microbiology, 41(6), 464-469.

Mulla, M., Ahmed, J., Al-Attar, H., CastroAguirre, E., Arfat, Y. A., \& Auras, R. (2017). Antimicrobial efficacy of clove essential oil infused into chemically modified LLDPE film for chicken meat packaging. Food Control, 73, 663-671.

O' Callaghan, K. A. M., \& Kerry, J. P. (2014). Assessment of the antimicrobial activity of potentially active substances (nanoparticled and non-nanoparticled) against cheesederived microorganisms. International Journal of Dairy Technology, 67(4), 483489.

Olasupo, N. A., Fitzgerald, D. J., Gasson, M. J., \& Narbad, A. (2003). Activity of natural antimicrobial compounds against Escherichia coli and Salmonella enterica serovar Typhimurium. Letters in Applied Microbiology, 37(6), 448-451.

Ouattara, B., Simard, R. E., Piette, G., Bégin, A., \& Holley, R. A. (2000). Inhibition of surface spoilage bacteria in processed meats by application of antimicrobial films prepared with chitosan. International Journal of Food Microbiology, 62(1), 139-148.

Ozdemir, M., \& Floros, J. D. (2001). Analysis and modeling of potassium sorbate diffusion through edible whey protein films. Journal of Food Engineering, 47(2), 149-155.

Ozdemir, M., \& Floros, J. D. (2004). Active food packaging technologies. Critical Reviews in Food Science and Nutrition, 44(3), 185-193. 


\section{Food and Health, 4(1): 63-79 (2018)}

\section{Journal abbreviation: Food Health}

Panea, B., Ripoll, G., González, J., FernándezCuello, Á., \& Albertí, P. (2014). Effect of nanocomposite packaging containing different proportions of $\mathrm{ZnO}$ and $\mathrm{Ag}$ on chicken breast meat quality. Journal of Food Engineering, 123, 104-112.

Patiño, J. H., Henríquez, L. E., Restrepo, D., Mendoza, M. P., Lantero, M. I., \& García, M. A. (2014). Evaluation of polyamide composite casings with silver-zinc crystals for sausages packaging. Food Packaging and Shelf Life, 1(1), 3-9.

Pekcan, G., Köksal, E., Küçükerdönmez, O., \& Ozel, H. (2006). Household food wastage in Turkey. Rome, Italy: FAO.

Perez, L. M., Soazo, M. D., Balague, C. E., Rubiolo, A. C., \& Verdini, R. A. (2014). Effect of $\mathrm{pH}$ on the effectiveness of whey protein/glycerol edible. films containing potassium sorbate to control non-O157 shiga toxin-producing Escherichia coli in ready-toeat foods. Food Control, 37, 298-304.

Pires, A. C. D., Soares, N. D. F., de Andrade, N. J., do Silva, L. H. M., Camilloto, G. P., \& Bernardes, P. C. (2008). Development and Evaluation of Active Packaging for Sliced Mozzarella Preservation. Packaging Technology and Science, 21(7), 375-383.

Rhim, J. W., Park, H. M., \& Ha, C. S. (2013). Bionanocomposites for food packaging applications. Progress in Polymer Science, 38(10-11), 1629-1652.

Rhim, J. W., Wang, L. F., \& Hong, S. I. (2013). Preparation and characterization of agar/silver nanoparticles composite films with antimicrobial activity. Food Hydrocolloids, 33(2), 327-335.

Ripoche, A. C., Chollet, E., Peyrol, E., \& Sebti, I. (2006). Evaluation of nisin diffusion in a polysaccharide gel: Influence of agarose and fatty content. Innovative Food Science \& Emerging Technologies, 7(1-2), 107-111.

Rodriguez-Martinez, A. V., Sendon, R., Abad, M. J., Gonzalez-Rodriguez, M. V., BarrosVelazquez, J., Aubourg, S. P., . . de Quiros, A. R. B. (2016). Migration kinetics of sorbic acid from polylactic acid and seaweed based films into food simulants. LWT-Food Science and Technology, 65, 630-636.
Sanchez-Valdes, S., Ortega-Ortiz, H., Valle, L. F. R. D., Medellin-Rodriguez, F. J., \& GuedeaMiranda, R. (2009). Mechanical and Antimicrobial Properties of Multilayer Films with a Polyethylene/Silver Nanocomposite Layer. Journal of Applied Polymer Science, 111(2), 953-962.

Sebti, I., Carnet, A. R., Blanc, D., Saurel, R., \& Coma, V. (2003). Controlled Diffusion of an Antimicrobial Peptide from a Biopolymer Film. Chemical Engineering Research and Design, 81(9), 1099-1104.

Shemesh, R., Krepker, M., Goldman, D., DaninPoleg, Y., Kashi, Y., Nitzan, N., . . . Segal, E. (2015). Antibacterial and antifungal LDPE films for active packaging. Polymers for Advanced Technologies, 26(1), 110-116.

Silveira, M. F. A., Soares, N. F. F., Geraldine, R. M., Andrade, N. J., \& Goncalves, M. P. J. (2007). Antimicrobial efficiency and sorbic acid migration from active films into pastry dough. Packaging Technology and Science, 20(4), 287-292.

Siripatrawan, U., \& Noipha, S. (2012). Active film from chitosan incorporating green tea extract for shelf life extension of pork sausages. Food Hydrocolloids, 27(1), 102-108.

Siripatrawan, U., \& Vitchayakitti, W. (2016). Improving functional properties of chitosan films as active food packaging by incorporating with propolis. Food Hydrocolloids, 61, 695-702.

Sohaib, M., Anjum, F. M., Arshad, M. S., \& Rahman, U. U. (2016). Postharvest intervention technologies for safety enhancement of meat and meat based products; a critical review. Journal of Food Science and Technology-Mysore, 53(1), 1930.

Song, H., Li, B., Lin, Q. B., Wu, H. J., \& Chen, Y. (2011). Migration of silver from nanosilverpolyethylene composite packaging into food simulants. Food Additives \& Contaminants: Part A, 28(12), 1758-1762.

Soysal, C., Bozkurt, H., Dirican, E., Guclu, M., Bozhuyuk, E. D., Uslu, A. E., \& Kaya, S. (2015). Effect of antimicrobial packaging on physicochemical and microbial quality of chicken drumsticks. Food Control, 54, 294299. 


\section{Food and Health, 4(1): 63-79 (2018)}

\section{Journal abbreviation: Food Health}

Sung, S.-Y., Sin, L. T., Tee, T.-T., Bee, S.-T., Rahmat, A., Rahman, W., Tan, A. C., \& Vikhraman, M. (2013). Antimicrobial agents for food packaging applications. Trends in Food Science \& Technology, 33(2), 110-123.

Takala, P. N., Vu, K. D., Salmieri, S., Khan, R. A., \& Lacroix, M. (2013). Antibacterial effect of biodegradable active packaging on the growth of Escherichia coli, Salmonella typhimurium and Listeria monocytogenes in fresh broccoli stored at 4 degrees C. LWTFood Science and Technology, 53(2), 499506.

Teerakarn, A., Hirt, D. E., Acton, J. C., Rieck, J. R., \& Dawson, P. L. (2002). Nisin diffusion in protein films: Effects of film type and temperature. Journal of Food Science, 67(8), 3019-3025.

von Goetz, N., Fabricius, L., Glaus, R., Weitbrecht, V., Gunther, D., \& Hungerbuhler, K. (2013). Migration of silver from commercial plastic food containers and implications for consumer exposure assessment. Food Additives \& Contaminants: Part A, 30(3), 612-620.
Wang, H. L., Hao, L. L., Wang, P., Chen, M. M., Jiang, S. W., \& Jiang, S. T. (2017). Release kinetics and antibacterial activity of curcumin loaded zein fibers. Food Hydrocolloids, 63, 437-446.

Wang, H. L., Zhang, R., Zhang, H., Jiang, S. W., Liu, H., Sun, M., \& Jiang, S. T. (2015). Kinetics and functional effectiveness of nisin loaded antimicrobial packaging film based on chitosan/poly(vinyl alcohol). Carbohydrate Polymers, 127, 64-71.

Yoshida, C. M. P., Bastos, C. E. N., \& Franco, T. T. (2010). Modeling of potassium sorbate diffusion through chitosan films. LWT - Food Science and Technology, 43(4), 584-589.

Zendo, T., Nakayama, J., Fujita, K., \& Sonomoto, K. (2008). Bacteriocin detection by liquid chromatography/mass spectrometry for rapid identification. Journal of Applied Microbiology, 104(2), 499-507.

Zhou, F., Ji, B. P., Zhang, H., Jiang, H., Yang, Z. W., Li, J. J., Li, J. H., Ren, Y. L., \&Yan, W. J. (2007). Synergistic effect of thymol and carvacrol combined with chelators and organic acids against Salmonella typhimurium. Journal of Food Protection, 70(7), 1704-1709. 